\title{
PEMANFAATAN BUDAYA LOKAL TERHADAP TEKNOLOGI PENANGKAPAN IKAN PADA MASYARAKAT NELAYAN Studi Kasus Di Kabupaten Pidie Jaya, Provinsi Aeeh
}

Teuku Muhammad Faisal Program Magister Manajemen Sumberdaya Pantai Universitas

\author{
Diponegoro
}

\begin{abstract}
In fishing communities, fishing activities are strongly influenced by local culture. The communities use \{heir hiowledge of local, social, cultural, religious system to labor at seas. The knowledge involves the use of technology, including charts and fishing boats which have been used for generations to survive households from poverty and vulnerability.
\end{abstract}

Keywords '.fishing communities, social and cultural system, Pidie Jaya

\section{Pendahuluaa}

Pada umumnya, masyarakat yang tinggal di tepi-tepi laut terutama di kawasm pesisir pantai barat Sumatera bermata pencaharian sebagai nelayan. Sebagian besar menggunakan teknologi penangkapan ikan yang masih bersifat trdisional dan sebagian kecil memiliki alat penangkapan yang modem. Secara garis besar nelayan berdasarkan alat penangkapan ikan dapat dibedakan atas dua golongan, yaitu:

1. Berdasarkan kepemilikan alat penangkapan, nelayan terbagi atas:

a. Nelayan pemilih yaitu nelayan yang mempunyai alat penangkapan baik yang langsung turun ke laut maupun yang langsung menyewakan alat tangkapan kepada orang lain.

b. Nelayan Buruh atau nelayan penggarap, yaitu nelayan yang tidak memiliki alat penangkap, tetapi mereka menyewa alat tangkap dari orang lain atau mereka yang menjadi buruh atau pekerja pada orang yang mempunyai alat penangkapan.

2. Berdasarkan sifat kerja nelayan, dapat dibedakan atas:

a. Nelayan penuh atau nelayan asli, yaitu nelayan baik yang mempunyai alat tangkap atau buruh yang berusaha semata-mata pada sektor perikanan tanpa memiliki usaha yang lain.

b. Nelayan Sambilan, yaitu nelayan yang memiliki alat penangkapan atau juga sebagai buruh pada saat tertentu melakukan kegiatan pada sektor perikanan di samping usaha lainnya.

Secara sosial budayadikemukakan bahwa masyarakat nelayan memiliki ciri - ciri yang saling terkait antara satu dengan yang lainnya. Alasannya adalah (1) terdapat interaksi sosial yang intensif antara warga masyarakat, yang ditandai dengan efektifnya komunikasi tatap muka sehingga terjadi hubungan yang sangat erat antara satu dengan yang lainnya Dengan demikian hal tersebut dapat membangun terjalinnya hubungan kekeluargaan yang didasarkan pada simpati dan bukan berdasarkan kepada pertimbangan rasional yang berorientasi kepada untung rugi. (2) bahwa dalam mencari nafkah mereka menonjolkan sifat gotong royong dan saling membantu. Hal tersebut dapat diamati pada mekanisme menangkap ikan baik dalam cara penangkapan maupun dalam penentuan daerah operasi (Dirjen Kebudayaan Depdikbud, 
1997).

Artikel ini membahas ten tang pemanfaatan budaya lokal terhadap teknologi penangkapan ikan pada masyarakat nelayan di Kabupaten Pidie Jaya, Provinsi Aceh dan sejauh mana perkembangan budaya lokal yang direspon oleh masyarakat nelayan terhadap teknologi penangkapan ikan sehingga para nelayan dapat memanfaatkan teknologi tersebut dengan mengikuti perkembangan zaman moderen.

\section{Pembahasan}

\subsection{Gambaran Umum Wilayah Kabupaten Pidie Jaya}

Kabupaten Pidie Jaya terletak pada koordinat $60 " 10^{\prime}-50^{\circ} 30^{\prime}$ Lintang Utara dan $450^{\circ} 97^{\prime \prime}-96^{\mathrm{fl}} 35^{\prime}$ Bujur Timur mempakan pemekaran dari Kabupaten Pidie dengan jumlah penduduk pada tahun 2006 mencapai 139.779 jiwa yang terdiri dari laki-laki 65.117 jiwa atau $46,59 \%$ dan perempuan $74.662 \mathrm{j}$ iwa atau 53,41\%.

Luas wilayah Kabupaten Pidie Jaya secara keseluruhan mencapai $1.162,84 \mathrm{~km}^{2}$ atau 116,284 hektar, dengan batas-batasnyasebagai berikut:

1. Sebelah Utara dengan Selat Malaka;

2. Sebelah Selatan dengan Kabupaten Pidie;

3. Sebelah Timur dengan Kabupaten Bireuen; dan

4. Sebelah Barat dengan Kabupaten Pidie.

Kota Meureudu merupakan ibukota Kabupaten Pidie Jaya. Kota ini terletak di pesisir timur Kabupaten Pidie Jaya. Sektor perikanan laut dan budidaya sangat bagus di Pidie Jaya untuk dikembangkan (Dishubkominfo Provinsi Aceh,2009), $\wedge 3$

2.2 Tradisi dengan Teknologi Menangkap (Meupayang) Masyarakat Nelayan di Pidie Jaya yang Dipengaruhi oteh Budaya Lokal
Masyarakat nelayan Aceh, khususnya nelayan yang ada di Kabupaten Pidie Jaya mengenal beberapa teknik penangkapan ikan di laut dan teknik ini diatur dalam Hukum Adat Laot, seperti Palong, Pukat Longgm, PukatAceh, Perahoe, Jalo, Jeue, Jareng, Ruleue, Kawego, Kawetieh Geurungom, Bube, Sawold Sareng, Jang, Jeureumai danNyap.

Palong adalah alat tangkap sejenis jaring berbentuk persegi panjang yang dibentangkan secara horisontal dengan kayu atau bambu sebagai kerangkanya. Palong dibangun di atas perahu atau didirikan di tengah laut. Di Aceh Selatan disebut Bagan. Jenis-jenis ikan yang ditangkap antara lan: hileh $t>u$ (ten nasi), suree (tongkol), noh (axri-cumi).

Pukat (beach seine) dioperasikan di daerah pantai atau sekitar muara. Pukat digunakan dalam dua cara: 1) laboh darat:

menggiring dan menarik pukat yang direntangkan di laut ke arah pantai. Pukat ini hanya bisa digunakan pada pantai tak berkarang dan hanya boleh dilakukan di lokasi-lokasi tertentu yang telah ditetapkan oleh Panglima Laot, yang disebut Iheun; dan 2) laboh loot melabuh pukat di tengah laut atau biasa disebut meupayang. Seringkai dilakukan pada saat musim ombak besar sehingga suiit melabuh pukat di pantai. Seringkali pula dilakukan pada saat musim ikan pelagis ('http://panglimalaotaceh.org/artikel/. 2011). Kegiatan nelayan di Kabupaten Pidie Jaya umumnya dilakukan secara berkelompok tetapi ada juga yang melakukannya secara perorangan. Kegiatan tersebut sebagian besar dilakukan oleh laki laki yang berumur di atas 15 tahun.

\section{Musim dan Cuaca}

Pengetahuan nelayan terhadap kondisi cuaca sangat penting untuk keberhasilan mereka dalam menangkap 
ikan dan untuk keselamatan mereka dalam mencari ikan di taut. Seorang pawang mempunyai pengetahuan yang lebih mengenai kondisi cuaca sebagai pedoman bagi para nelayan untuk turun kelaut.

Pada masyarakat nelayan Piidie Jaya, kondisi cuaca yang baik untuk pergi melaut adalah apabila langit di laut cerah dan bersih, tetapi apabila di laut gelap maka nelayan tidak akan perg ke laut dikarenakan diperkirakan akan turun hujan dan terjadi badai sehingga dapat membahayakan keselamatan nelayan itu sendiri.

Selain itu juga dengan melihat bintang pada malam hari. Apabila bintang banyak dan ada diantaranya yang masuk ke dalam lingkaran bulan maka diperkirakan hari tersebut baik untuk pergi melaut.

Menurut hasil wawancara diketahui bahwa apabila bintang kalo yaitu rasi bintang yang berbentuk kalajengking yang letaknya berdekatan dengan bulan muncul maka sebagai pertanda kondisi cuaca akan buruk atau badai akan datang.

Selain itu gejala akan terjadinyabadai adalah langit tertutup awan hitam, gelombang air laut tinggi dan angin bertiup sangat kencang, Terjadinya pergeseran bulan dan bintang yang seakan-akan sal ing bertabrakan menandakan juga akan terjadinya cuaca yang buruk.

Selain bintang, pertanda lainnya untuk dapat melaksanakan kegiatan melaut adalah perputaran angin yang lebih dikenal dengan angin utara dan angin barat. Angin ini muncul pada malam hari yang berhembus dari utara atau barat dengan kecepatan yang sangat tinggi yang mengakibatkan cuaca akan berubah menjadi buruk sehingga mengakibatkan ombak yang sangat tinggi serta arus air akan kencang sehingga akan mempengaruhi proses penangkapan ikan.
Sabda, Volume 8, Tahun 2013 : 73-82 Angin timur dan angin selatan tidak begitu mengganggu atau menyulitkan nelayan karena angin ini hanya berhembus perlahan-lahan.

Apabila bulan baru muncul maka arus air akan bergelombang atau arus air berjalan di dalam laut sedangkan kalau bulan akan terbenam maka arus air akan tenang dan biasanya arus air itu selalu berlawanan dengan arah angin.

Selain hal tersebut di atas, letak awaa yang berbedapun akan mempengaruhi datangnya badai. Apabila awan terletak di arah selatan matahari terbit menandakan badai akan bertiup dari selatan, sebaliknya bila awan terletak di bagian barat matahari maka badai juga akan datang dari arah barat. Bila awan berada tepat di atas matahari Juga akan menandakan akan datangnya badai. Tetapi tidak semua awan yang berada di dekat matahari akan mendatangkan badai dan cuaca buruk, seperti awan yang tergantung dekat di atas matahari yang akan tenggelam. Hal ini menandakan kondisi cuaca akan baik karena angin yang sedang berhembus akan reda. Kemudian dari letak bintang apabila muncul bintang timur akan menandakan kondisi cuaca yang baik.

Musim ikan biasanya tidak sepanjang tahun. Dalam satu tahun sekitar bulan April sampai dengan bulan Agustus menandakan bahwa produksi ikan melimpah yang diperoleh oleh nelayan. Untuk bulan lainnya biasanya perolehan ikan sulit didapat. Pertanda akan musim ikan berlimpah adalah bergerombolnya awan besar di atas permukaan laut dengan berbagai ikan seperti ikan tongkol dan tuna Selain itu adanya gerombolan elang laut yang sedang berputar-putar di atas permukaan laut menandakan bahwa di sekitar atau di bawah permukaan laut terdapat banyak jenis ikan seperti ikan-ikan kecil (ikan teri).

Untuk menghindari terjadinya cuaca 
\$abda, Volume 8, Tahun 2013 : 73-82

yang buruk ketika melaut maka tungganai biasanya menyuruh kepada awak kapal supaya berlabuh ke pulau terdekat dan kalau tidak sempat maka terpaksa mencari pengamanan sendiri dengan cara memakai pelampung atau jerigen untuk berenang.

\subsection{Teknologi Penangkapan Ikan}

Dalam menangkap ikan dengan palong (bagan) banyak peralatan yang dibutuhkan nelayan untuk dapat memperoleh hasil tangkapan yang banyak. Peralatan dalam membagan tidak hanya membagi peralatan intinya saja seperti waring sebagai alat utama dalam penangkapan ikan, tetapi juga ada peralatan pendukung lainnya yang memiliki peran penting dalam penangkapan ikan. Peralatan waring berbentuk segi empat bujur sangkar yang ukurannya berkisar 18-20 m.

Waring berbentuk segi empat bujur sangkar dikarenakan harus disesuaikan dengan bentuk dan ukuran lengan bagan atau palong (dalam bahasa aceh) yang sekaligus dijadikan sebagai cadik dan ukuran cadik tersebut berbentuk bujur sangkar, sedangkan ukuran waring disesuaikan dengan besarnya bagan. Kalau bagannya besar misal panjangnya $20 \mathrm{~m}$ dan lebamya $4 \mathrm{~m}$ maka biasanya waringnya berukuran $20 \times 20 \mathrm{~m}$ dan kalau bagannya berukuran panjang $12 \mathrm{~m}$ dan lebar $2 \mathrm{~m}$ maka ukuran watingnya. $18 \times 18 \mathrm{~m}$, sedangkan panjang ke bawahnya tidak ditentukan. Hal tersebut tergantung kemauan orang yang mempunyai waring.

Peralatan lainnya adalah jangkar, iampu TL neon. Jangkar tersebut terbuat dari besi yang memiliki dua buah ujung yang berbentuk sebuah kail. Jangkar berbentuk kail agar kalau jangkar dijatuhkan ke dasar laut maka akan tersangkut di batu karang. Jangkar ini berfungsi untuk menahan bagan supaya tetap di tempat dan jangkar ini diletakkan atau diikatkan di kepala bagan supaya bagan tidak berputar apabila ada angin yang berhembus atau ada gelombang yang besar.

Jangkar ini dilengkapi dengan tali yang berguna untuk menurunkan dan menaikkan yang terbuat dari benang nilon. Peralatan lainnya yang sangat penting adalah Iampu TL neon. Lampu TL neon ini berbentuk bulat sebanyak 1 GO-ISO buah. Nelayan menggunakan Iampu TL neon ini karena sewaktu ikan sudah berada di atas waring dan lampu dimatikan satu persatu ikan tersebut tidak terkejut dan tidak akan lari sebab dengan memakai Iampu bulat tersebut apabila dimatikan jarak antara Iampu yang satu dengan Iampu lainnya tidak terlalu jauh. Lampu TL neon ini berjumlah sekitar 100-150 buah yang disesuaikan dengan besarnya cagak atau kayu yang dipergunakan untuk meletakkan lampuTI neon tersebut.

Lampu neon ini mempunyai kekuatan 32 watt yang disesuaikan dengan besarnya ember atau kuali yang dipergunakan untuk meletakkan Iampu TL neon tersebut. Lampu TL neon ini ditempetkan pada ember atau kuali dengan cara mengikatkannya dan kemudian turo diikatkan pada cagak atau kayuyangtelahdisediakan.

Peralatan yang paling penting lainnya adalah Jaring. Jaring yang diperguakan untuk menangkap ikan ini panjangnya lebih kurang 800-1000 m, 400 in di sebelah kiri dan $400 \mathrm{~m}$ di sebelah kanan. Panjang jaring ini disesuaikan dengan kemampuan orang yang memiliki jaring tersebut Jaring ini bentuknya seperti celana panjang yang mempunyai dua buah kaki dan di tengah-tengahnya dibuat seperti pinggang celana supaya ikan akan terkumpul di dalamnya dan pada waktu menariknya ikan ini tidak akan keluar.

Menangkap ikan dengan memukat menggunakan peralatan yaitu jaring dan sebuah perahu kecil. Jaring yang dipergunakan panjangnya lebih kurang 
300 m. Panjang jaring tidak ditentukan secara pasti, di mana hal tersebut tergantung kepada orang yang mempunyai jaring tersebut. Pada masyarakat Pidie Jaya jaring yang dipergunakan oleh nelayan untuk menangkap ikan rata-rata panjangnya $300 \mathrm{~m}$ (DKPPidie Jaya, 2010).

Jaring ini biasanya ditambah lagi dengan tali yang panjangnya $200 \mathrm{~m}$ dan tali ini adalah sebagai penarik jaring ke tepi laut yang panjangnya $100 \mathrm{~m}$ di sebelah kiri dan $100 \mathrm{~m}$ di sebelah kanan. Tali ini sama panjang dikarenakan ketika akan menarik jaring ke tepi harus sama serentak antara orang yang menarik di sebelah kiri dengan onmg yang disebelah kanan dari orang yang memberikan aba-abaditengahlaut.

Peralatan lain yang diperlukan adalah sebuah perahu yang didayung, Perahu ini panjangnya $5 \mathrm{~m}$ dan lebar $1 \mathrm{~m}$. Perahu ini berfungsi untuk membawa jaring ke tengah laut dan kemudian dengan perahu tersebut, nelayan akan kembali ke tengah laut untuk memberikan aba-aba kepada orang yang berada di tepi pantai untuk menarik jaring tersebut, Orang yang berada di tengah laut memberikan aba-aba dengan menggunakan dayung yaitu apabila tarikan orang yang di tepi pantai yang di sebelah kanan perahu cepat maka la akan mengangkat dayungnya dengan tangan kanan. Hal tersebut sebagai pertanda bagi orang yang di sebelah kiri tepi pantai untuk mempercepat tarikannya, sehingga penarikan jaring akan sama lagi dan begitujuga sebaliknya sampai jaring terbawa seluruhnya ke tepi pantai.

Teknologi pada penangkapan ikan menjaring menggunakan peralatan jaring dan perahu. Jaring yang selalu dipergunakan oleh masyarakat nelayan Pidie Jaya adalah yang berukuran 100-200 $\mathrm{m}$. Jaring ini ada yang jahitannya halus dan kasar. Jaring yang halus ukuran
Sabda, Volume 8. Tahun 2013: 73-82 matanya memiliki panjang $25-20 \mathrm{~cm}$ dan lebamya kira-kira $5 \mathrm{~cm}$, sedangkan jaring yang jahitannya kasar ukuran matanya memiliki panjang 50-60 cm dan lebar $10 \mathrm{~cm}$. Untuk jahitan yang kasar adalah untuk menangkap ikan yang besar-besar sepeni ikan suree (tongkol), noh (cumi-cumi), sedangkan jahitan yang halus atau rapat adalah untuk menangkap ikan yang kecil-kecil seperti udeung sabee (rebon), hileh $b u$ (teri nasi).

Penangkapan ikan dengan menjaring mempergunakan sebuah perahu yang panjangya lebih kurang $4 \mathrm{~m}$ dan lebamya $1 \mathrm{~m}$. Perahu yang banyak digunakan oleh masyarakat nelayan Pidie Jaya saat ini sudah banyak memakai mesin perahu/mesin tempel. Sebelum memakai mesin tempel, masyarakat nelayan Pidie Jayadalam menjalankan perahu memakai mesin untuk pengukur kelapa yang diengkol atau ditarik (DKP Pidie Jaya 2010).

2.5 Sistem Kepercayaan pantangao dalam Masyarakat Nelayan

Dalam melaksanakan akti vitas penangkapan ikan masyarakat nelayan Pidie Jaya menganut kepercayaan dan pantangan yang tidak boleh dilakukan oleh para nelayan. Seperti hari Jumat, ada empat alasan mengapa hari Jumat ditetapkan sebagai hari pantang melaut bagi nelayan Aceh khuzusnya nelayan di Pidie Jaya. Pertama karena alasan religius- Bagi nelayan yang muslim, hari libur melaut itu mereka manfaatkan untuk menunaikan kewajiban shalat Jumat berjamaah. Kalau nelayan tetap melaut hampir tak mungkin bagi mereka menunaikan shalat Jumat secara berjamaah tepat wdktu (Abdullah, 2010).

Alasan kedua karena pertimbangan. ekologis. Dihampirkan dalam seminggu harus ada satu hari di mana seluruh biota laut hidup tenang tanpa diusik oleh para 
Sabda, Volume 8, Tahun 2013: 73-82

nelayan, sehingga memungkinkan ikan, udang dan lainnya berpijah- Masa tenang itu ditetapkan hari Jumat Ketiga, karena alasan reparasi. Hari tidakmelaut itu, bisa digunakan para nelayan untuk memperbaiki jala, jaing, pukal perahu atau boatnya sehingga ketika turun rnelaut lagi kondisi alat-alat tangkapnya dalam keadaan prima.

Pada masa mereparasi alat tangkap itu biasanya terjalin pula nilai-mlai komunal (kerja sama atau kegotong-royongan), sebab pekerjaan memperbaiki alat tangkap itu biasanya dilakukan bersama-sama oleh kelompok nelayan sebeldm waktu shatat Jumat tiba. Inilah alaSBrt keempat. mengapa Jumat ditetapk\&fl sebagai hari pantang meiaul hagi •»eluruh nclinan - Iceli unuiniin.i Jan diharapkJn iuga hahwa dengan adanva hari lihur ini memungkinkan para nelayan dapat berkumpul kembali dengan keluarganya. setelah hari-hari melaut (Abdullah, 2010).

2.6 Huhungan Teknologi dan Budaya Penangkapan ikan dengan Pemasaran Ikan Dalam Peningkatan TarafHidup Ekonomi Masyarakat

\subsubsection{Pembagian hasil ikan}

Hasil tangkapan ikan yang diperoleh langsung dibawa ke tempat pendaratan ikan tradisional dan di sana sudah ada agen atau pembeli yang menanti. Biasanya agen-agen tersebut telah ditentukan oleh toice (pemilik modal). Alasan lain nelayan menjual ikan di tempat pendaratan ikan tradisional karena semua jenis ikan dapat diterima baik besar maupun kecil, begitu juga dengan jenis-jenisnya. Setelah ikan diberikan kepada agen kemudian kapal (bagan/palong) dibawa kembali ke tepi pantai Kabupaten Pidie Jaya. Setelah tiba di tepi lalu diikatkan dan kemudim dibersihkan karena setelah menangkap ikan perahunya bau anyir.

Ikan yang telah dijual dari setiap kali membagan uangnya tidak langsung dibagikan tetapi disimpan di kas yang dipegang oleh toke. Pembagian hasil tangkapan secara kesehiruhan dilakukan pada hari berikutnya setelah ikannya dibeli semua oleh agen atau pembeli. Sebelum hasil dibagikan, terlebih dahulu potong biaya-biaya yang sebelumnya seperti biaya BBM, makanan dan minum dan perbaikan-perbaikan lainnya. Setelah semua biaya yang terpakai terpotong; maka uang yang tersisa dibagi dua, setengah untuk pemilik bagan atau te kryi (pemilik modal) dan setengah lagi untuk anggota bagan. Hasil keseluruhan dibagi dua dulu karena yang menyediakan semua peralatan dan makanan adalah toke taped kemudian dari separuh untuk anggota tersebut dibagi sama rata.

Untuk pembagian hasi! tangkapan ikan nieliilui akiivitas penangkupan ikan memikut i.tiin nicn|arin^ hia,sanlii ikan-ikiin Jnii<t,sukkan kc dalani ember alau keraniang dan hid^amu sudah ada agen-agen kei-il >ang menunggu untuk membelinya langsung. Setelah ikan di jual maka hasilnya langsung dibagi sama rata.

\subsubsection{Keberadaan Tempat Pelelangan Ikan (TPI)}

Umumnya masyarakat nelayan di Pidie Jaya memasarkan ikan langsung ke TPI (Tempat Pelelangan Ikan), namun ada juga pembeli (konsumen) yang membeli ikan ke Pasar Ikan yang ada di Kota Kecamatan yang sudah dibeli oleh penjual ikan dari agen di TPI (Tempat Pelelangan Ikan).

\subsubsection{Pen garuh Budaya Lokal Setempat Terhadap Usaha Pemberdayaan}

Dengan asumsi tiap rumah tangga nelayan memiliki 6 jiwa maka sekurang-kurangnya terdapat 12 juta jiwa yang menggantungkan hidupnya sehari-hari pada sumber daya laut termasuk pesisir tentunya. Mereka pada umumnya mendiami daerah kepulauan, sepanjang pesisir termasuk danau dan sepanjang aliran sungai. Penduduk tersebut tidak seluruhnya menggantungkan hidupnya dari kegiatan menangkap ikan akan tetapi 
iTiasib ada bidang bidang lain seperti usaha pariwisata bahari, pengangkutan antar pulau danau dan penyeberangan, pedagang perantara/eceran hasil tangkapan nelayan, penjaga keamanan laut, penambangan lepas pantai dan usaha-usaha lainnya yang berhubungan dengan laut dan pesisir (Zamzami,2007).

Sudah sejak dari dahulu sampai sekarang nelayan hidup dalarn suatu organisasi kerja secara turun temurun tidak mengalami perubahan yang berarti. Kelas pemilik sebagai juragan kesejahteraannya relatif lebih baik karena menguasai faktor produksi seperti kapa], mesin alat tangkap maupun faktor pendukungnya seperti es. garam dan lainnya. Kelas lainnva yang merupakan niayoritas idalah pekerjaataupenerima upahdari pemilik taklor produksi dan kaiaupun mereka mengusahakan sendiri faktor/alat produksinya masih sangat konvensional, sehingga produktivitasnya tidak berkembang. Kelompok inilah yang terus berhadapan dan digeluti oleh kemiskinan (Kusnadi, 2005).

Zamzami(2007) juga menyebutkan bahwa rumah tangga nelayan pada umunnya memiliki persoalan yang lebih kompiek dibandingkan dengan rumah tangga pertanian. Rumah tangga nelayan memiliki ciri khusus seperti penggunaan wilayah pesisir dan lautan common properti sebagai faktor produksi, jam kerja yang harus mengikuti siklus bulan yaitu dalam 30 hari satu bulan yang dapat dimanfaatkan untuk melaut hanya 20 hari sisanya mereka relatif menganggur. Selain daripada itu pekerjaan menangkap ikan adalah merupakan pekerjaan yang penuh resiko dan umumnya karena itu hanya dapat dikerjakan oleh lelaki. Hal ini mengandung arti keluarga yang lain tidak dapat membantu secara penuh.

Dengan persoalan yang demikian tentunya harus dipahami bahwa rumah tangga nelayan memerlukan perhatian yang multi dimensi. Tantangan yang terbesar adalah bagaimana membangun sektor ini agar dapat mengangkat harkat dan martabat kehidupan masyarakat nelayan maupun masyarakat lainnya yang terkait dengan sumber daya
Sabda, Volume 8, Tahun 2013 : 73-82

kelautan dan pesisir. Masalah pembangunan nelayan adalah masalah manajemen pengembangan masyarakat pesisir yang meliputi tiga masalah yaitu: masalah sosial ekonomi rumah tangga nelayan, masalah kenapa mereka miskin dan selanjutnya bentuk intervensi yang bagaimana diperlukan. Selanjutnya jika didasarkan pada dimensi waktu maka kebijakan pembangunan rumah tangga nelayan dibagi menjadi tiga dimensi waktu yaiu kebijakan jangka panjang, jangka menengah dan jangka pendek

Masyarakat Kabupaten Pidie Jaya yang merupakan wilayah baru dari hasil pemekaran kabupaten Pidie ini sebagian besar hekerfa sebagai netayan dikarenakan mereka tinggal di daerah yang paling Jekal dengan lepi panliii. Dari sumber data nelayan DKP Pidie Jaya (2010) yang diperoleh oleh penults. diketahui bahwa masyarakat yang bekerja, sebagai nelayan disebabkan daerah ini dekat dengan pantai dan mereka tidak mempunyai keahlian daiam bidang lainnya. Nelayan yang sudah tua pun banyak yang masih melaut dikarenakan sudah tidak ada pekerjaan yang lain yang dapat mereka lakukan dan masih mempunyai kemampuanpergi kelaut.

\subsubsection{Peran Istri Nelayan dalam Menuiiiang Ekononii Rumeh Tangga di Kabupaten Pidie Jaya}

Perempuan nelayan adalah suatu istilah untuk perempuan yang hidup di lingkungan keluarga nelayan, baik sebagai istri maupun anak dari nelayan pria. Kaum perempuan di keluarga nelayan umumnya terlibat dengan aktif mencari nafkah untuk keluarganya. Selama ini perempuan nelayan bekerja menjadi pengumpul kerang-kerangan, pengolah hasil ikan, pembersih perahu yang baru mendarat, pengumpul nener, membuat/memperbaiki jaring, pedagang ikan dan membuka warung. Namun peran perempuan di lingkungan nelayan ini belum dianggap berarti, sebagai penghasil pendapatan keluarga pun dianggap income tambahan. Selain itu perempuan nelayan pun menanggung resiko tinggi akibat 
Sabda, Volume Q, Tahun 2013 : 73-82

tingginya kecelakaan kerja di usaha penangkapan ikan laut ini (Zamzami,2007).

Pengalaman menunjukan bahwa pemberdayaan wanita nelayan dalam pembangunan kelautan dan perikanan sulit dikembangkan, hal ini disebabkan karena kurangnya IPTEK dan kemiskinan yang selalu mendera mereka. Beberapa masalah dalam integrasi perempuan nelayan dalam pembangunan kelautan dan perikanan antara lain : pendidikan yang umumya sangat rendah, tenaga perempuan sering tidak dinilai, masih adanya nilai-nilai sosial budaya masyarakat sebagai penghambat berperan sertanya perempuan nelayan secara aktif. sedangkan beban kerja perempuan dalam keluarga cukup tinggi.

Dalam masyarakat nelayan Kabupaten pidie Jaya terutama istri para nelayan berinisiatif bekerja menambah pendapatan keluarga dipicu oleh kondisi buruk yang selalu dihadapi nelayan seperti peagumpul kerang-kerangan, pengolah fosil ikan, pembersih perahu yang harus mendarat, pengumpul nener, membuat memperbiki jaring, dagang ikan dan memjangka warung. Tidak pemah harga ikan hasil tangkapan suami mereka stabil. Selain itu faktor naik turunnya harga ikan, masa-masa paceklik yang tidak dapat dihindari, maupun tekanan kenaikan harga-harga kebutuhan pokok, di antaranya harga bahan bakar kapal, membuat kehidupan nelayan tak pernah jauh dari kemiskinan. Dengan modal yang terbatas, usaha yang dijalani masih dalam skala rumah tangga.

Urn urn ny a mereka juga masih berpandangan yang penting adalah sikius hidup dapat dijalani. Kepasrahan pada keadaan memangmenjadi ciri khas perempuan nelayan, terlebih di waktu sekarang di mana perolehan ikan suami makin berkurang, kualitas ikan kurang baik, sehingga perempuan nelayan terpaksa turut andi I berusaha mencari tambahan penghasilan hanya sekadar untuk mencukupi kebutuhan keluarga.

Pada masyarakat nelayan Pidie Jaya terdqpat organisasi sosial baik formal maupun nonformal. Formal seperti LSM Yayasan Citra. Desa Indonesia (YCDI), namun tidak begitu berpengaruh kepada masyarakat tersebut, di mana lebih aktif organisasi yang terbentuk secara swadaya atau disebut kelompok sosial. Kelompok sosial ini yang mengkoordinir apabila ada terjadi kecelakaan atau terjadi keterlambatan neiayan untuk pulang dari Jadwal yang sudah ada maka nelayan-nelayan lain dengan sukarela membantu untuk mencari nelayan tersebut. Wadah ini terjadi dengan sendirinya tanpa ada yang mendirikan. Selain itu juga terdapat tradisional ntuk membantu nelayan lain.

\section{Simpulan}

Dari uraian E dapat dilihat bahwa sebagian besar masyarakat Kabupaten Pidie Jaya Provinsi Aceh bermata pencaharian sebagai nelayan. Hal ini disebabkan oleh faktor geografis di mana wilayah Kabupaten Pidie Jaya terutama ibu kotanya, kota Meureudu yang terletak di Pesisir pantai utara Aceh yang berhubungan tangsung dengan Selat Malaka dan hampir sebagian besar letak geografisnya memanjang di pinggiran pantai yang merupakan salah satu faktor yang terus dipergunakan untuk kelangsungan hidup masyarakat yang ada di Kabupaten Pidie Jaya.

Nelayan dalam memperoleh hasil tangkapan ikan di laut memiliki budaya dan teknologi penangkapan ikan yang telah ada sejak nenek moyangnya yang diwariskan secara turun temurun dari generasi ke generasi dan juga diperoleh dengan cara mempelajari pengalaman-pengalaman dari orang sebelumnya serta nilai-nilai yang beriaku dalam masyarakat yang tidak terlepas dari budaya lokal yang mereka miliki.

Kapal/boat sebagai salah satu teknologi ikan yang dipergunakan oleh nelayan yang ada di Kabupaten Pidie Jaya hampir sebagian besar kapal/boat bantuan dari Pemerintah dan NGO-Asing pasca Tsunami 2004. Dengan adanya boat bantuan ini, maka akan meringankan nelayan-nelayan yang ada di kabupaten Pidie 
Jaya.

Masyarakat Nelayan Kabupaten Pidie Jaya sendiri memiliki sistem pengetahuan terhadap hal yang berhubungan dengan aktivitas penangkapan ikan di laut. Sistem pengetahuan tersebut berupa informasi mengenai banyaknya produksl ikan di beberapa lokasi yang menyebabkan para nelayan memperoleh hasil ikan yang maksimal, yaitu di dekat tubi atau pinggir batu karang yang didiami oleh ikan - ikan keel. Untuk ikan besar biasanya berada di tengah laut. Selain itu, pengetahuan akan kondisi cuaca dan musim "•angat mempengaruhi aktivitas penangkapan kan di laut. Pengetahuan tentang kapan waktu $\cdot$ i.urun ke laut dan kembali ke darat juga aempengaruhi aktivitas penangkapan ikan ^lelayandi Kabupaten Pidie Jaya.

Masyarakat nelayan di Kabupaten Pidie Jaya, secara umum memiliki cara tersendiri dalam tradisi menangkap ikan. Masyarakat nelayan Aceh mengenat beberapa teknik penangkapan ikan di laut dan teknik ini diatur dalam Hukum Adat Laut, seperti Palong, Pukat langgar, Pukat Aceh, Perahoe, Jalo, Jeue, Jareng Ruleue, Kawego, Kawetieh Geunengom, Bube e, SawoldSmeng, Jang, Jeureumai, dan Nyap.

Pelaksanaan aktivitas penangkapan ikan pada masyarakat Kabupaten Pidie Jaya banyak dipengaruhi oleh adanya kepercayaan-kepercayaan dan pantangan-pantangan yang tidak boleh dilakukan oleh para nelayan seperti larangan melaut di hari Jum'at. Apabila hal tersebut dilakukan maka akan menimbulkan f.uaca buruk atau badai dan juga akan menghalangi rezeki atau tidak akan inendapatkan ikan. Larangan tersebut berdasarkan kepercayaan secara religi dan ketetapan dari lembaga adat laot yang ada di Aceh yaitu Panglima Laot.

Hasil tangkapan ikan yang diperoleh langsung dibawa ke tempat pelelangan ikan tradisional yang ada di seputaran pantai Kabupaten Pidie Jaya atau dipasarkan langsung ke pasar ikan yang ada di kota kecamatan. Namun ada juga pembeli (konsumen) yang membeli ikan langsung ke kapal saat
Sabda, Volume 8, Tahun 2013 : 73-82 pendaratan ikan. Umumnya kondisi ini didapatkan di pantai Lueng Putu Pante Raja, Trienggadeng dan Meureudu. Sampai saat ini peran Tempat Pelelangan Ikan Tradisional (TPIT) sudah mampu meningkatkan perekonomian masyarakat nelayan.

Adapun peran dari istri-istri nelayan balk secara swadaya maupun individual dalam berbagai aktivitas juga memberikan dampak positif dalam mendukung kelangsungan hidup untuk memenuhi kebutuhan sehari-hari. Adanya inisiatif untuk mencari tambahan penghasilan seperti membuka warung makan, membantu usaha suami dalam budidaya laut dan sebagai pengolah ikan.

\section{DaftarPustaka}

Abdullah, A. 2010. Melaut Hari Jumat dalam Lembaga Adat Laot Aceh (Panglima Laot). BandaAceh.

DKP Pidie Jaya. 2010. Data Statistik Produktivitas Nelayan Kabupaten Pidie Jaya Tahun 2010. 120 halaman. Meureudu.

Dirjen Kebudayaan Depdikbud. 1997. Budaya Kerja Nelayan Indonesia di Jawa Timur. Jakarta: CVBuparaNugraha.

Dishubkominfo Provinsi Aceh. 2009. Data Profit Kabupaten/ Kota dalam Provinsi Aceh Tahun 2009. Seksi Bank Data, Bidang Manajemen Database, Pelayanan Media dan Informasi. BandaAceh.

Kusnadi. 2005. Akar Kemiskinan Nelayan. Yogyakarta:LkiS.

Zamzami, L, dkk. 2007. "Pengaruh Budaya Lokal terhadap Teknologi Penangkapan Ikan pada Nelayan di Pasar Laban Kelurahan Bungus Selatan, Kecamatan Bungus Teluk Kabung, Kota Padang". Artikel IlmiahAntropologi. Padang.

$\underline{\text { http ://pangl imalaotaceh.org/arti ke 1/Peran dan }}$ 
Sabda, Volume 8, Tahun 2013:73-82

Fungsi Kelembagaan Adat PangHma Laot dalam Pengelolaan SumberdayaKelautan dan Perikanan. Diakses Senin, 30 Mei 2011pukul20:35wib. 